\title{
PENGARUH PERBEDAAN JENIS PAKAN ALAMI (Skeletonema sp., Chaetosceros sp., Tetraselmis sp.) TERHADAP LAJU PERTUMBUHAN DAN KANDUNGAN NUTRISI PADA Artemia sp.
}

\section{EFFECT OF DIFFERENT LIVE FEED TYPE (Skeletonema sp., Chaetosceros sp., Tetraselmis sp.) TO THE GROWTH RATE AND NUTRITIONAL CONTENT ON Artemia sp.}

\author{
Muhammad Yohan Firmansyah, Rahayu Kusdarwati dan Yudi Cahyoko \\ Fakultas Perikanan dan Kelautan Universitas Airlangga \\ Kampus C Mulyorejo - Surabaya, 60115 Telp. 031-5911451
}

\begin{abstract}
Artemia is an important live feed in the hatchery. Quality of Artemia can not be separated from the feed quality that given. The quality and quantity of feed in the waters constitute factors that determine the growth rate and nutrition contentent the Artemia. This study aims to determine effect of different live feed type to the growth rate and nutritional content on Artemia sp.. The research method used was experimental with Completely Randomized Design (CRD) using four treatments and five replications. The treatments used were: silage fish (A), Skeletonema sp. (B), Chaetoceros sp. (C) and Tetraselmis sp. (D). Analysis of data uses Anova. To know the difference among the treatments were done by Duncan Multiple range test. The results showed that difference of natural feed influence highly significant $(p<0,05)$ on the rate of growth in absolute length and significant influence $(p<0,05)$ on average daily growth weight of Artemia sp. Absolute length growth rate was highest in treatment D $(3,92 \mathrm{~mm})$, then a row followed by treatment $\mathrm{C}(3,275 \mathrm{~mm}), \mathrm{A}(1,89 \mathrm{~mm})$ and $\mathrm{B}(1,775 \mathrm{~mm})$. The daily growth rate of weight was highest in treatment D $(25,43 \%)$, then a row followed by treatment C $(21,91 \%), \mathrm{B}(19,24 \%)$ and A $(18,77 \%)$. . Artemia that given live feed produces highest nutritional value of D (protein 44,96\%; carbohydrate $18,47 \%$ and fat $26,91 \%$ ) wasted Tetraselmis sp. and the lowest obtained by treatment A (protein 41,21\%; carbohydrate 8,88\% and fat 29,1\%) wasted silage fish. Water quality during Artemia cultivation was temperature $28-32^{\circ} \mathrm{C}, \mathrm{pH} 7$, dissolved oxygen $5-8 \mathrm{mg} / \mathrm{L}$, salinity $31 \mathrm{ppt}$ and ammonia 0 $0,25 \mathrm{mg} / \mathrm{L}$.
\end{abstract}

Keywords : Artemia sp., live feed, growth and nutritional content

\section{Pendahuluan}

Artemia merupakan pakan alami yang penting dalam pembenihan ikan laut, crustacea, ikan konsumsi dan ikan hias. Disamping ukurannya yang kecil, nilai gizi Artemia juga sangat tinggi yang menghasilkan pertumbuhan sangat cepat. Artemia sebagai pakan alami belum dapat digantikan oleh pakan lainnya sehingga dapat dijadikan usaha industri dalam kaitannya dengan suplai makanan hidup maupun bahan dasar utama makanan buatan (Jusadi, 2003).

Artemia bersifat pemakan segala atau omnivora. Makanannya berupa plankton, detritus,dan partikel-partikel halus yang dapat masuk mulut. Artemia dalam mengambil makanan bersifat penyaring tidak selektif (non selective filter feeder) sehingga apa saja yang dapat masuk mulut Artemia seakan-akan menjadi makanannya. Akibatnya kandungan gizi Artemia sangat dipengaruhi oleh kualitas pakan yang tersedia pada perairan tersebut (Isnansetyo dan Kurniastuti, 1995).
Kandungan komposisi nutrisi Artemia dipengaruhi oleh beberapa faktor, antara lain: strain, kualitas, kondisi media tempat Artemia hidup dan ketersediaan makanan (Harefa, 2003). Jenis makanan Artemia pada budidaya di bak yaitu antara lain: mikroalgae (Chaetoceros, Nitzchia, Dunaliella, Isochrysis, Chorella, Skeletonema, Tetraselmis), kemudian makanan tambahan (ragi roti, ragi bir, ragi laut), serta makanan dari sisa produksi pertanian seperti dedak halus, tepung kedelai, dan dedak gandum (Mudjiman, 1989).

Pakan alami yang digunakan sebagai pakan dalam pemeliharaan Artemia adalah Tetraselmis sp., Chaetoceros sp. dan Skeletonema sp. (Djarijah, 1995). Kelebihan ketiga jenis pakan tersebut, antara lain: Tetraselmis mempunyai nilai gizi tinggi karena mengandung protein 49,1\%, lemak $10,7 \%$, karbohidrat $19 \%$ dan abu 19,1\%. Chaetoceros sp. mengandung protein 35\%; lemak 6,9\%; karbohidrat $6,6 \%$ dan kadar abu $28 \%$ persen (Gusrina, 2008). Skeletonema mempunyai nilai 
gizi kandungan protein 24,7\%; lemak 2,6\%; karbohidrat $20,2 \%$ dan abu $51,8 \%$ (Isnansetyo dan Kurniastuti 1995).

Beberapa faktor yang perlu diperhatikan dalam penyediaan pakan, yaitu jumlah dan kualitas pakan (Mujiman, 1989). Kualitas dan kuantitas pakan pada perairan merupakan faktor yang menentukan laju pertumbuhan dan nutrisi Artemia. Hubungan kualitas dan kuantitas pakan terhadap laju pertumbuhan dan kandungan nutrisi Artemia, yaitu ketersediaan pakan secara kuantitas dan kualitas merupakan faktor mempengaruhi nutrisi Artemia. Ketersediaan nutrisi merupakan faktor yang menentukan laju pertumbuhan, sehingga jumlah dan kualitas pakan merupakan faktor utama untuk memenuhi kandungan nutrisi Artemia untuk berkembang dengan optimal.

Berdasarkan latar belakang tersebut dilakukan penelitian pengaruh pemberian jenis pakan alami yang berbeda terhadap laju pertumbuhan dan kandungan nutrisi pada Artemia. Diharapkan dari hasil penelitian ini dapat diketahui jenis fitoplankton yang sesuai bagi pembudidayaan Artemia yang dapat menghasilkan pertumbuhan dan kandungan nutrisi yang baik.

\section{Metodologi}

Bahan penelitian terdiri atas hewan uji, pakan uji dan bahan pendukung penelitian. Hewan uji yang digunakan adalah Artemia. Pakan uji yang diberikan adalah Skeletonema sp., Chaetosceros sp. dan Tetraselmis sp. Pupuk cair sebagai suplai nutrien fitoplankton. Semua bahan didapatkan di BBAP Situbondo.

Alat-alat yang digunakan meliputi botol bervolume 1,5 liter sebanyak 20 buah, mikroskop, kamera, aerator, selang aerator, gelas ukur, erlenmeyer, pipet tetes, termometer, pipet volume, mikroskop, Sedgewich Rafter, Haemocytometer, refraktometer, $\mathrm{pH}$ meter, timbangan digital analitik dan lampu.

Data yang diperoleh, dianalisa dengan menggunakan analisis ragam (ANAVA) untuk mengetahui apakah ada pengaruh antara perlakuan yang diberikan. Bila ada pengaruh perlakuan dilanjutkan dengan uji Jarak Berganda Duncan dengan tingkat kepercayaan 95 persen dan selang kesalahan 5 persen untuk mengetahui perbedaan antar perlakuan (Kusriningrum, 2008).

Prosedur Penelitian

Persiapan media pemeliharaan berbagai jenis fitoplankton meliputi air laut untuk media pemeliharaan disterilkan dengan menggunakan kaporit atau klorin 20 ppm minimal selama 24 jam dan dinetralkan dengan larutan natrium thiosulfat $10 \mathrm{ppm}$ untuk menghilangkan sisa klorin dalam air laut. Perangkat yang terbuat dari kaca disterilkan dengan autoklaf. Sebelumnya peralatan kaca dicuci bersih dengan menggunakan detergen, kemudian ditiriskan hingga kering. Setelah kering masing-masing dibungkus dengan alumunium foil, untuk erlenmeyer dan tabung reaksi ditutup dengan kapas dan dibungkus dengan alumunium foil. Setelah itu disterilisasi menggunakan autoklaf dengan suhu $121^{\circ} \mathrm{C}$ dan tekanan 1 atm selama 30 menit (Isnansetyo dan Kurniastuty, 1995).

Skeletonema sp., Chaetosceros sp. dan Tetraselmis sp. didapatkan di BBAP Situbondo kemudian dilakukan pemeliharaan di bak pakan alami yang telah disterilisasi. Bibit di masukkan ke dalam bak kemudian ditambahkan pupuk yang telah dipersiapkan. Pencahayaan dilakukan dengan menggunakan lampu TL. Artemia dipersiapkan dengan menetaskan kista terlebih dahulu melalui proses dekapsulasi. Artemia yang telah menetas dimasukkan ke dalam media bervolume 1,5 liter dengan kepadatan 2000 ekor/liter.

Pemberian pakan pada Artemia dilakukan pada fase instar II sampai berumur 7 hari secara ad-libitum. Pemberian pakan fitoplankton berupa Chaetosceros sp., Tetraselmis sp. dan Skeletonema sp. yang memenuhi kebutuhan pakan Artemia, yaitu $22.500 \mathrm{sel} /$ ekor. Pemberian pakan pada Artemia dilakukan dengan system inlet-outlet. Penghitungan dilakukan dengan menggunakan Sedgewick Raffter atau Haemocytometer dan Handtally Counter untuk memudahkan perhitungan. Suhartono dkk. (2008) menjelaskan, kebutuhan silase ikan sebagai pakan Artemia, yaitu 0,2 mg/ekor.

Pengukuran laju pertumbuhan yang diukur meliputi panjang dan berat Artemia. Pengukuran dilakukan setiap harinya yang meliputi panjang Artemia menggunakan mikrometer. Widiarti (1986) menjelaskan, pengukuran berat biomassa Artemia dilakukan pada awal dan akhir penelitian, ditimbang berdasarkan berat basah dengan cara mengambil sampel dari setiap pelakuan. Sampel diambil sebanyak $100 \mathrm{ml}$ kemudian dituang diatas mesh dan dilakukan perhitungan jumlah Artemia yang terambil pada sampel $100 \mathrm{ml}$. Mesh diletakkan di mulut gelas agar air dapat menetes keluar, letakkan kertas hisap dibagian bawahnya bila sudah tidak ada air yang menetes hingga tidak terdapat noda pada kertas hisap maka dilakukan penimbangan yang sebelumnya mesh telah 
ditimbang terlebih dahulu. Selisih berat antara sebelum dan sesudah diberi Artemia dibagi dengan jumlah Artemia yang ditemukan pada sampel akan menghasilkan rata-rata berat individu Artemia. Analisa kandungan nutrisi pada Artemia dilakukan pada tahap akhir dari penelitian ini.

\section{Hasil dan Pembahasan}

Laju Pertumbuhan Panjang Artemia sp.

Hasil pengamatan penelitian pengaruh perbedaan jenis pakan alami pada Artemia sp. berupa data panjang. Pertumbuhan panjang Artemia sp. disajikan dalam bentuk panjang mutlak yang diperoleh dari panjang awal dan akhir. Hasil pengukuran panjang mutlak Artemia sp. dapat dilihat pada Tabel 1.

Tabel 1. Data laju pertumbuhan panjang mutlak (mm) Artemia sp. selama tujuh hari

\begin{tabular}{|c|c|}
\hline Perlakuan & Pertambahan panjang $(\mathrm{mm}) \pm \mathrm{SD}$ \\
\hline A & $1,89^{\mathrm{c}} \pm 0,14$ \\
B & $1,775^{\mathrm{c}} \pm 0,256$ \\
C & $3,275^{\mathrm{ab}} \pm 1,054$ \\
D & $3,925^{\mathrm{a}} \pm 0,447$ \\
\hline
\end{tabular}

Keterangan: Superskrip berbeda dalam satu kolom menunjukkan perbedaan sangat nyata $(\mathrm{p}<0,05)$.

Perlakuan A : pemberian pakan berupa silase ikan (kontrol)

Perlakuan B : pemberian pakan berupa Skeletonema sp.

Perlakuan C : pemberian pakan berupa Chaetoceros sp.

Perlakuan D : pemberian pakan berupa Tetraselmis sp.

SD : standar deviasi

Berdasarkan Tabel 1 diketahui bahwa pertumbuhan panjang mutlak tertinggi diperoleh D $(3,925)$ yang tidak berbeda nyata $(\mathrm{p}>0,05)$ dengan perlakuan $\mathrm{C}(3,275)$, namun berbeda sangat nyata $(\mathrm{p}<0,05)$ pada perlakuan A $(1,89)$ dan B (1,775). Perlakuan terendah diperoleh perlakuan A yang tidak berbeda nyata $(\mathrm{p}>0,05)$ perlakuan $\mathrm{B}$, namun berbeda sangat nyata $(\mathrm{p}<0,05)$ pada perlakuan $\mathrm{C}$ dan $\mathrm{D}$.

Pertumbuhan Berat Artemia sp.

Hasil pengamatan penelitian pengaruh perbedaan jenis pakan alami pada Artemia sp. berupa data berat rata-rata harian. Pertumbuhan berat Artemia sp. disajikan dalam bentuk ratarata harian yang diperoleh dari berat awal dan akhir. Data laju pertumbuhan harian berat Artemia sp. dapat dilihat pada Tabel 2.
Tabel 2. Data laju pertumbuhan harian rata-rata berat (\%) Artemia sp selama tujuh hari.

\begin{tabular}{|c|c|c|}
\hline $\begin{array}{c}\text { Perla } \\
\text { kuan }\end{array}$ & LPH $(\%) \pm$ SD & $\begin{array}{c}\text { Transformasi } \sqrt{y} \\
\pm S D\end{array}$ \\
\hline A & $18,7782 \pm 3,356$ & $4,2922^{\mathrm{d}} \pm 0,665$ \\
B & $19,2409 \pm 3,065$ & $4,3751^{\mathrm{c}} \pm 0,352$ \\
C & $21,9179 \pm 2,248$ & $4,6768^{\mathrm{b}} \pm 0,238$ \\
D & $25,4333 \pm 2,119$ & $5,039^{\mathrm{a}} \pm 0,21$ \\
\hline
\end{tabular}

Keterangan: Superskrip berbeda dalam satu kolom menunjukkan perbedaan yang nyata $(\mathrm{p}<0,05)$.

Perlakuan A : pemberian pakan berupa silase ikan (kontrol)

Perlakuan B : pemberian pakan berupa Skeletonema sp.

Perlakuan C : pemberian pakan berupa Chaetoceros sp.

Perlakuan D : pemberian pakan berupa Tetraselmis sp.

SD : standar deviasi

Berdasarkan Tabel 2 diketahui bahwa pertumbuhan berat tertinggi diperoleh perlakuan D $(25,43 \%)$ yang berbeda nyata $(\mathrm{p}<0,05)$ dengan perlakuan C $(21,91 \%)$, B $(19,24 \%)$ dan A $(18,77 \%)$. Perlakuan $\mathrm{C}$ berbeda nyata $(\mathrm{p}<0,05)$ dengan perlakuan A, B dan D. Perlakuan B berbeda nyata dengan perlakuan A, $\mathrm{C}$ dan D. Pertumbuhan berat terendah diperoleh perlakuan A yang berbeda nyata $(\mathrm{p}<0,05)$ dengan perlakuan $\mathrm{B}, \mathrm{C}$ dan $\mathrm{D}$.

Nilai Nutrisi Artemia sp.

Hasil pengamatan penelitian pengaruh perbedaan jenis pakan alami terhadap kandungan nutrisi pada Artemia sp. berupa data sampel total dari setiap perlakuan yang mewakili semua ulangan dan dianalisa nilai nutrisinya berdasarkan berat basah kemudian nilai kandungan yang ada dikonfersikan pada nilai berat kering. Data analisa nutrisi Artemia sp. dapat dilihat pada Tabel 3.

Berdasarkan Tabel 3 diketahui bahwa nilai nutrisi pada setiap perlakuan berbeda, yaitu: Perlakuan A (protein 41,21\%; karbohidrat $8,88 \%$, lemak 29,1\%), B (protein 44,26\%; karbohidrat 1,05\%, lemak 38,09\%), C (protein $44,39 \%$; karbohidrat 9,79\%, lemak 28,89\%) dan D (protein 44,96\%; karbohidrat $18,47 \%$, lemak 26,91\%).

Kualitas Air

Pertumbuhan Artemia sp. selain dipengaruhi oleh ketersediaan pakan juga dipengaruhi oleh faktor lingkungan. Pengukuran suhu dilakukan dua kali sehari pada pagi dan sore hari, sedangkan pengukuran salinitas dan 
Tabel 3. Data analisa komposisi tubuh Artemia sp. dalam berat kering.

\begin{tabular}{|c|c|c|c|c|c|c|}
\hline Perlakuan & $\begin{array}{c}\text { Protein } \\
(\%)\end{array}$ & $\begin{array}{c}\text { KH/BETN } \\
(\%)\end{array}$ & $\begin{array}{c}\text { Lemak } \\
(\%)\end{array}$ & $\begin{array}{c}\text { SK } \\
(\%)\end{array}$ & $\begin{array}{c}\text { Abu } \\
(\%)\end{array}$ & $\begin{array}{c}\sum \text { Energi } \\
(\text { Kcal } / \mathrm{kg})^{*}\end{array}$ \\
\hline A & 41,21 & 8,88 & 29,10 & 9,52 & 11,29 & 5319,9 \\
B & 44,26 & 1,05 & 38,09 & 7,14 & 9,54 & 5987,8 \\
C & 44,39 & 9,79 & 28,89 & 7,75 & 9,18 & 5516,2 \\
D & 44,96 & 18,47 & 26,91 & 6,26 & 3,40 & 5723,1 \\
\hline
\end{tabular}

Keterangan:

Perlakuan A : pemberian pakan berupa silase ikan (kontrol)

Perlakuan B : pemberian pakan berupa Skeletonema sp.

Perlakuan C : pemberian pakan berupa Chaetoceros sp.

Perlakuan D : pemberian pakan berupa Tetraselmis sp.

$*$ Energi total dimana $1 \mathrm{gr}$ protein $=5,6 \mathrm{kkal}, 1 \mathrm{gr}$ lemak = 9,1 kkal, 1 gr karbohidrat $=4,1 \mathrm{kkal}$

(Jauncy and Ross, 1982)

pH dilakukan hanya pada pagi hari. Pengukuran kadar amoniak dan DO dilakukan di awal, pertengahan dan akhir masa pemeliharaan. Data parameter kualitas air selama penelitian terdapat pada Lampiran 5 yang menjelaskan bahwa nilai kisaran saat penelitian untuk suhu $28-32^{\circ} \mathrm{C}$, pH 7, DO 5-8 mg/l, Amoniak 0-0,25 mg/l, salinitas 31 ppt dan data nilai kisaran kualitas air penelitian dapat dilihat pada tabel 4 .

Tabel 4. Nilai kisaran kualitas air media pemeliharaan Artemia sp. selama tujuh hari

\begin{tabular}{|c|c|}
\hline Parameter & Kisaran \\
\hline Suhu $\left({ }^{\circ} \mathrm{C}\right)$ & $28-32$ \\
$\mathrm{pH}$ & 7 \\
$\mathrm{DO}(\mathrm{mg} / \mathrm{l})$ & $5-8$ \\
Amoniak $(\mathrm{mg} / \mathrm{l})$ & $0-0,25$ \\
Salinitas $(p p t)$ & 31 \\
\hline
\end{tabular}

Pertumbuhan adalah pertambahan ukuran panjang dan berat pada makhluk hidup. Vos and Rosa (1980) menjelaskan bahwa faktor yang mempengaruhi pertumbuhan Artemia sp. adalah faktor internal dan faktor eksternal. Artemia sp. dipelihara selama tujuh hari mengalami kenaikan laju pertumbuhan panjang dan berat. Perbedaan laju pertumbuhan panjang pada Artemia sp. antar perlakuan disebabkan karena adanya perbedaan kandungan nutrisi dalam pakan yang diberikan. Hal ini sesuai pernyataan Harefa (2003) menyatakan bahwa salah satu faktor yang mempengaruhi pertumbuhan, yaitu kandungan nutrisi pada pakan.

Perbedaan laju pertumbuhan harian Artemia sp. pada masing-masing perlakuan juga dipengaruhi oleh kelengkapan dan keseimbangan jumlah nutrisi yang terdapat pada pakan yang diberikan. Pemberian pakan berupa Tetraselmis sp memberikan laju pertumbuhan tertinggi. Hal ini diduga disebabkan karena pakan perlakuan pemberian pakan Tetraselmis sp. memiliki kandungan protein yang tinggi jika dibandingkan dengan silase ikan, Skeletonema sp. dan Chaetoceros sp., selain itu Tetraselmis memiliki kandungan nutrisi yang lengkap dan kelebihannya, antara lain: memiliki kandungan omega 3 dan 6 sebesar 8,1\% (Supriantini dkk., $2007 \mathrm{~b}$ ); asam amino yang tinggi yaitu leusin $10,3 \%$, treonin $9,8 \%$ asam glutamat $8,4 \%$, alanin $8,1 \%$ (Fahardian et al., 2009) dan tidak memiliki dinding sel sehingga dimungkinkan lebih mudah dicerna (Hastuti, 1989).

Perlakuan pemberian pakan berupa Chaetoceros sp. menghasilkan laju pertumbuhan lebih rendah namun tidak berbeda dengan perlakuan pemberian pakan berupa Tetraselmis sp. Hal ini diduga kelengkapan nutrisi antara Tetraselmis sp. dan Chaetoceros sp. mendominasi pakan jika dibandingkan Skeletonema sp. dan silase ikan. Adapun kelebihan pakan Chaetoceros sp. yang menghasilkan laju pertumbuhan lebih tinggi dibandingkan perlakuan pemberian pakan berupa silase ikan dan Skeletonema sp., antara lain: mengandung omega 3, EPA, DHA dan bkaroten yang merupakan pro vitamin A yang cocok untuk pertumbuhan zooplankton (Sutomo dkk., 2007); memiliki kandungan kalsium $0,59 \%$ dan phosphor $0,57 \%$ dimana kalsium berperan dalam pembentukan sel dan phospor berperan dalam pembentukan protein (Isnansetyo dan Kurniastuty, 1995) dan memiliki kandungan asam amino tertinggi yaitu fenilalanin 13,1\% dan alanin 9,8\% (Fahardian et al., 2009). 
Laju pertumbuhan terendah didominasi pada perlakuan pemberian pakan berupa silase ikan yang tidak berbeda nyata dengan perlakuan pemberian pakan berupa Skeletonema sp. Hal ini diduga kelengkapan nutrisi dari kedua pakan tersebut belum memenuhi kebutuhan Artemia sp. selain itu Skeletonema sp. memiliki nilai nutrisi lebih rendah, antara lain: protein $24,7 \%$, lemak 2,6\%, karbohidrat 20,2\%, dan abu 51,8\% (Isnansetyo dan Kurniastuti, 1995). Hal ini menjelaskan bahwa nilai nutrisi Skeletonema sp. lebih rendah jika dibandingkan dengan Tetraselmis sp., yaitu protein $49,1 \%$, lemak $10,7 \%$, karbohidrat $19 \%$, abu 19,1\% (Gusrina, 2008) dan Chaetoceros sp., yaitu protein $35 \%$, lemak 6,9\%, karbohidrat 6,6\%, abu $28 \%$ (Isnansetyo dan Kurniastuti, 1995).

Silase ikan yang memiliki nilai protein $38,77 \%$, lemak $15,11 \%$, karbohidrat $32,95 \%$, abu $6,9 \%$ tidak memberikan laju pertumbuhan yang tinggi jika dibandingkan dengan pemberian pakan Chaetoceros sp. dan Tetraselmis sp., hal ini diduga kelengkapan nilai nutrisi pakan buatan berbeda dengan nilai nutrisi pakan hidup. Kelebihan pakan alami jika dibandingkan pakan buatan sebagai pakan, antara lain: memiliki kandungan gizi lebih lengkap dan tinggi, isi sel padat dan dinding sel tipis sehingga mudah diserap dan dicerna, cepat berkembang biak dan memiliki toleransi yang cukup tinggi terhadap perubahan faktor lingkungan, pergerakan pakan alami tidak begitu aktif sehingga mudah ditangkap dan selama dikultur tidak mengeluarkan senyawa yang bersifat racun (Hastuti, 1989).

Hasil penelitian ini menjelaskan bahwa nilai nutrisi penting berupa kandungan protein, lemak dan karbohidrat mempengaruhi laju pertumbuhan pada Artemia sp. dikarenakan dari setiap nutrisi pada pakan yang diberikan memiliki fungsi yang berbeda dan saling melengkapi untuk pertumbuhan. Herawati (2005) menjelaskan, fungsi dari protein antara lain: pemeliharaan jaringan tubuh yang rusak, pertumbuhan, pembentuk sistem enzim dalam sistem pencernaan dan sebagai sumber energi dalam pembentukan telur dan reproduksi. Fungsi lemak adalah sebagai sumber energi, membantu penyerapan mineral-mineral serta vitamin yang terlarut dalam lemak (vitamin A, D, E, K), selain itu keberadaan lemak membantu proses metabolisme untuk pertumbuhan dan menjaga keseimbangan daya apung di dalam air. Murtidjo (2001) menjelaskan bahwa karbohidrat merupakan sumber energi untuk pertumbuhan dan metabolisme. Karbohidrat diserap dalam dinding usus dalam bentuk monosakarida, yakni glukosa, fruktosa dan galaktosa. Glukosa merupakan hasil akhir dari pencernaan karbohidrat tingkat tinggi, suatu bentuk zat makanan yang beredar dalam darah dan dapat menghasilkan energi untuk pertumbuhan.

Laju pertumbuhan panjang dan berat Artemia sp. berbeda dikarenakan nilai nutrisi pada pakan yang diberikan berbeda. Saputra (2007) menyatakan bahwa pertumbuhan dapat didefinisikan pertambahan secara isometrik atau panjang dan allometrik atau volume sehingga pengukuran pertumbuhan dilakukan dengan mengukur panjang-berat Artemia sp. dan pertambahan panjang akan dihubungkan dengan pertambahan berat.

Berdasarkan analisa nutrisi Artemia sp. menunjukkan nilai kandungan protein dan lemak berbeda pada komposisi tubuh Artemia sp. Kadar protein tertinggi diperoleh pada perlakuan D sedangkan terendah pada perlakuan A. Hal ini diduga pakan perlakuan D memiliki nilai protein yang tinggi yakni $49,1 \%$ (Gusrina, 2008) sedangkan perlakuan A memiliki nilai protein hanya $38,77 \%$. Tetraselmis sp. yang mengandung protein $49,1 \%$ dapat digunakan sebagai pengganti sel yang rusak atau pembentukan sel yang baru dan akhirnya untuk pertumbuhan. Selama pemeliharaan ini tidak ada hubungan yang lurus antara kadar lemak pakan yang diberikan terhadap kandungan lemak tubuh Artemia sp.

Pertumbuhan Artemia sp. baik dipengaruhi oleh kandungan nutrisi selain itu juga dipengaruhi oleh kondisi lingkungan di dalam media pemeliharaan. Faktor lingkungan yang mendukung pertumbuhan Artemia sp. adalah suhu air, oksigen terlarut (DO), salinitas dan pH (Vos and Rosa, 1980). Srihartini (1992) menyatakan bahwa suhu air mempunyai pengaruh terhadap metabolisme suatu oraganisme. Hasil pengukuran suhu air selama penelitian berkisar antara $28-32^{\circ} \mathrm{C}$. Hasil pengukuran $\mathrm{pH}$ pada media pemeliharaan Artemia sp. selama penelitian adalah 7. Treece (2000) menyebutkan bahwa $\mathrm{pH}$ yang optimal untuk pertumbuhan Artemia sp. berkisar antara 7,0-8,5. Salinitas merupakan salah satu faktor pembatas yang sangat penting dalam budidaya Artemia, terutama dalam pertumbuhan dan menghasilkan kista (Sorgeloos, 1985). Hasil pengukuran salinitas pada media pemeliharaan Artemia sp. adalah 31 ppt.

Kadar oksigen terlarut sangat penting untuk kehidupan Artemia sp. Srihartini (1992) menyatakan bahwa kadar oksigen terlarut jika rendah dalam suatu perairan maka akan dapat mempengauhi kecepatan makan dan jika kadar oksigen berlebih akan mengakibatkan kematian 
disebabkan terjadi emboli gas pada pembuluh darah yang dapat mengakibatkan tertutupnya pembuluh darah. Hasil pengukuran oksigen terlarut selama penelitian berkisar antara 5-8 ppm Sumber amoniak di perairan dapat berasal dari sisa pakan maupun kotoran hasil metabolisme Artemia (Mukti dkk., 2003). Kadar ammonia selama penelitian berkisar antara 00,25 mg/l. Harefa (2003) menyatakan bahwa kadar ammonia terukur yang dapat menyebabkan kematian adalah lebih dari $1 \mathrm{ppm}$ (1 $\mathrm{mg} / \mathrm{l})$. Sumber amoniak pada perlakuan pemberian pakan buatan berupa silase ikan memberikan nilai kadar amoniak lebih tinggi dari pada pemberian pakan berupa Skeletonema sp., Chatosceros sp. dan Tetraselmis sp. hal ini dihubungkan pada laju pertumbuhan perlakuan pemberian pakan berupa silase lebih rendah. Amoniak dengan nilai yang lebih tinggi dapat mengakibatkan gangguan pada metabolisme Artemia sp. sehingga dapat menghambat pertumbuhan Artemia untuk berkembang biak.

\section{Kesimpulan}

Pemberian jenis pakan alami yang berbeda memberikan pengaruh terhadap laju pertumbuhan panjang Artemia sp. Pemberian jenis pakan alami yang berbeda memberikan pengaruh terhadap laju pertumbuhan berat Artemia sp. Pemberian jenis pakan alami yang berbeda memberikan pengaruh terhadap nilai nutrisi Artemia sp. Pemberian jenis pakan alami berupa Tetraselmis sp. dan Chaetoceros sp. memberikan pengaruh laju pertumbuhan terbaik bagi Artemia sp.

Berdasarkan hasil penelitian, maka disarankan untuk menggunakan pakan alami berupa Tetraselmis sp. atau Chaetoceros sp. untuk menghasilkan laju pertumbuhan yang tinggi pada Artemia sp.

\section{Daftar Pustaka}

Djarijah A. S. 1995. Pakan Alami. Kanisius. Yogyakarta. hal 44-71.

Fahardian O., Yusoff F. M. and S. Mohamed. 2009. Nutritional values of Apocyclops dengizicus (Copepoda: Cyclopoida) fed Chaetocerous calcitrans and Tetraselmis tetrathele. $w w w$. onlinelibrary.wiley.com. 08/01/2012.

Gusrina. 2008. Budidaya Ikan Jilid 2. Direktorat Jenderal Manajemen Pendidikan Dasar dan Menengah Departemen Pendidikan Nasional. Jakarta. hal 185-230.

Harefa F. 2003. Pembudidayaan Artemia untuk Pakan Udang dan Ikan. Penebar Swadaya. Jakarta. hal 14-25.
Hastuti W. 1989. Teknik Penyediaan Makanan Alami untuk Pembenihan Udang Skala Rumah Tangga. Departemen Pertanian. Direktorat Jendral Perikanan Balai Budidaya Air Payau Jepara. Jepara. hal 7-14.

Herawati V. E. 2005. Manajemen Pemberian Pakan Ikan. Universitas Diponegoro. Semarang. hal. 3-4.

Isnansetyo A. dan Kurniastusti. 1995. Teknik Kultur Phytoplankton dan Zooplankton:Pakan Alami untuk Organisme Laut. Kanisius. Yogyakarta. hal 36-52.

Jauncey K. and B. Ross. 1982. A guide to tilapia feeds and feeding. Institude of Aquaculture. University of Stirling. Scotland.

Jusadi D. 2003. Budidaya Pakan Alami. Direktorat Pendidikan. Direktorat Jenderal Pendidikan Dasar Dan Menengah Departemen Pendidikan Nasional. Jakarta. hal 12-16.

Kusriningrum. 2008. Perancangan Percobaan. Airlangga University Press. Surabaya.

Mudjiman, A. 1989. Udang Renik Air Asin (Artemia Salina). PT Bharata. Jakarta.

Mukti, A. T., M. Arief dan W. Hastuti. 2003. Dasar-dasar Akuakultur. Program Studi Budiaya Perairan. Fakultas Kedokteran Hewan. Universitas Airlangga. Surabaya. hal 42-44.

Murtidjo, B. A. 2001. Pedoman Meramu Pakan Ikan. Kanisius. Yogyakarta. 128 hal.

Saputra S. W. 2007. Dinamika Populasi. Program Studi Manajemen Sumberdaya Peraian Fakultas Perikanan dan Ilmu Kelautan Universitas Diponegoro. Semarang. hal 11.

Sorgelos P. 1985. Potential of Converting Microalgae Into Brine Shrimp Artemia. www.vliz.be/imisdocs/publications. 25/12/2011. 3 hal

Srihartini. 1992. Budidaya Ikan. Pusat Penelitian dan Pengembangan Fisika Terapan LIPI. Subang. 9 hal.

Suhartono, Adiwijaya D. dan T. Suprapto. 2008. Penggunaan Silase Ikan dalam Produksi Kista Artemia di Tambak Garam. www.isjd.pdii.lipi.go.id/. 24/12/2011. 12 hal.

Supriantini E., Widowati I. dan Ambariyanto. 2007b. Kandungan Asam Lemak Omega-3 (Asam Linoleat) pada Kerang Totok Polymesoda erosa yang diberi Pakan Tetraselmis chuii dan 
Skeletonema costatum. www.isjd.pdii .lipi.go.id. 06/01/2012. 7 hal.

Sutomo, Komala R., Wahyuni E.T. dan M. G. L. Pangabean. 2007. Pengaruh Jenis Pakan Mikroalgae Yang Berbeda Terhadap Pertumbuhan Populasi Rotifer. www.isjd.pdii.lipi.go.id/admin /jurnal/. 26/12/2011. 16 hal.

Treece G. D. 2000. Artemia Production for Marine Larval Fish Culture. Southern Regional Aquaculture Center through Grant No. 97-38500-4124 from the United States Department of Agriculture, Cooperative States Research, Education, and Extension Service. Texas. hal 2-3.

Vos J. and N. L. Rosa. 1980. Manual On Artemia Production In Salt Ponds In The Philippines. www.fao.org/. 12/12/2011. 3 hal.

Widiarti B. D. 1986. Pengaruh Pemberian Bekatul, Tepung Kedelai dan Campuran Kudeuanya sebagai Makanan Terhadap Produksi Artemia salina Leach. Institut Pertanian Bogor. Bogor. hal 47. 